\title{
Review Articles
}

\section{Study of Research Library}

\section{Problems}

Problems and Prospects of the Research Library. Edited by Edwin E. Williams. Published for the Association of Research Libraries. New Brunswick, N.J., Scarecrow Press, 1955. 181p. $\$ 4.50$.

This is a remarkable book. It is remarkable not for its content, which is probably known to all experienced research librarians, but because it represents a step forward in the furtherance of understanding between the top administration and faculty members of universities and their librarians. In many ways it represents a historic event, since librarians (39 of them) met with 20 professors, three vice-presidents, two presidents, and one chancellor to discuss the growth and financial problems of university libraries. Four of the librarians represented nonuniversity libraries: the John Crerar Library, the Newberry Library, the New York Public Library, and the Library of Congress.

Mr. Williams, who is to be congratulated for weaving into a single volume the miscellaneous papers and statements presented at the conference, held at Allerton House, Monticello, Illinois, October 29-31, 1954, introduces the volume with the following basic questions: "How much of the written record of civilization ought to be preserved, and how much of it can be? Whose is the responsibility? How should all that is preserved be organized for use?" The reader will not find answers to these questions in the volume. "The Monticello Conference was not expected to answer these questions or even much less basic ones. Rather, it was expected to ask questions suitable for consideration by a commission that the Association of American Universities hopes to sponsor," Mr. Williams observes.

It is unfortunate that not more than six vice-presidents or presidents attended the conference. Each institution belonging to the Association of Research Libraries or the
Association of American Universities was invited to send not only its librarian but also its president and one faculty member. On $\epsilon$ professor and one president who submitted papers for reading were not able to attend. It is unfortunate that more presidents or vice-presidents did not attend because the volume clearly suggests that they might have become educated to the ponderous problems of the major research libraries. In a letter to Robert B. Downs, chairman of the conference, Dr. Louis R. Wilson, dean emeritus of the Graduate Library School of the University of Chicago and former librarian of the University of North Carolina, wrote: "Unfortunately, the library is an area of university life about which the executives know far too little for the good of the total work of the institution. They know how to build buildings, to employ faculty members and work with trustees and legislatures and other problems of income, but they have not known the extent to which every class and research project depends upon the library for aid. They also are unaware of the fact, to a degree that is hardly pardonable, that the complexity of modern university libraries is such as to require skilled and welltrained personnel to direct and perform all of the library's work effectively."

The first session of the conference considered the general topic of "Opportunities and Pitfalls," and included papers by President Lloyd Morey of the University of Illinois, President John D. Millett of Miami University (he was unable to be present), Dr. Robert A. Miller, director of the Indiana University Library, and Professor Henry Gilman (Chemistry), Iowa State College. Dr. Miller discusses the reasons for the calling of the conference and emphasizes values as well as costs. Professor Gilman explains why well-stocked and well-administered libraries are needed by scientists. Dr. Millett comments on the misinterpretations of re. marks made about libraries and librarians in his Financing Higher Education in the United States. Dr. Millett would like to see librarians get closer to their administrations. One might say that many librarians would 
like to get closer, if their administrations would allow it. President Morey's remarks suggest that the presidents, as well as the librarians, have something to learn in this respect.

The second session of the conference was concerned with "Library Operation." Dr. Raynard C. Swank, director of the Stanford University Libraries, provides a "factsof-life" statement of what goes into "The Cost of Keeping Books." After a consideration of the characteristics of research and scholarship which affect the library directly, Dr. Swank reviews the elements of books and libraries which press upon costs. $\mathrm{He}$ then directs attention to eight areas for possible study by the proposed commission: (1) functions of the university in relation to library needs, (2) control of acquisitions, (3) weeding, (4) cataloging, (5) accessibility of collections, (6) nature of reference service, (7) library organization, and (8) management and equipment. Research librarians will appreciate the emphasis that is placed on functions. So long as university librarians are responsible for the integration of the facilities and services of their libraries into the sensitive fabric of expanding curricula and increasing enrollments, so long will it be necessary for university administrative officers to support the library programs.

Professor James D. Hart (English) of the University of California, in his discussion "What a Scholar Expects of Acquisitions," observes that "the professor accepts as axiomatic the necessity for growth of the library if his university is not to stagnate." With some realization that some corners must be cut, however, he proposes increased use of microreproductions, both within individual libraries and on a cooperative basis, the extension of the Farmington Plan, and the systematic development of interlibrary services (not just interlibrary loans).

Professors William B. Hamilton (History) of Duke University and Joseph S. Fruton (Biochemistry) of Yale University discuss the card catalog. Professor Hamilton, describing himself as "a fifth columnist in your midst," introduces his remarks with the statement, "I come not to bury the catalogue, but to praise it and to advocate its growth." The needs of the humanist and the social scientist cover wide areas and their rambling approaches require card catalogs and other sources as guides. He asks for more intensive subject analysis, and calls attention to inadequacies of the Library of Congress headings in specific situations. $\mathrm{He}$ is also critical of "overcorrectness" in author and subject entries. He would like to see well-developed dictionary (rather than divided) catalogs, the cataloging of documents, and the analysis of serials. Classification is not regarded as too significant, and limited funds should be put into subject cataloging. Professor Fruton observes that "classification is an essential operation whereas the worth of the subject catalogue is open to question." This is especially true, comments Professor Fruton, in libraries where the users have access to the shelves. Apparently, then, there are two sides to the question-as most librarians know. Get any group of professors -or just two of them-together and there is a conflict of opinion. Dr. Swank's concern for a study of the use of the catalog receives support from these comments. Professor Fruton also discusses the relation of card catalogs to other bibliographical apparatus, descriptive cataloging, the difficulty of finding materials issued by corporate bodies, the high cost of cataloging, and the usefulness of classified accession lists. $\mathrm{He}$ advocates partial reclassification for collections which have glaring deficiencies in arrangement.

From the standpoint of a professor of physics, Philip M. Morse of the Massachusetts Institute of Technology makes significant observations on "What Scholars Expect of Service to Readers." Speaking only for the physicist, he stresses the importance of recency of publication in his field. What to do with outmoded books is the librarian's problem. He notes: "I can only emphasize the fact that he [the physicist] does not want them on the shelves holding the books he is using daily, that he does want to get the new material there as quickly as possible, and that he wants to be able to find it without searching catalogues and classification systems." To find out how this can be done practically would indeed be a feather in the hat of the proposed commission. The suggestion of systematic discarding may be disconcerting to some librarians.

The third session was devoted to "Cooperation and Specialization." Dayton D. Mc- 
Kean, professor of political science and dean of the Graduate School at the University of Colorado, comments on "A Scholar's View of Cooperation." Appropriately, he takes exception to President Harold Dodds' statement that neither librarians nor faculties can be expected to be seriously interested in radical changes or economies and that "it seems to be generally agreed that if anything substantial is to be accomplished in the way of library economies it will be done only by the intervention of presidents and boards of trustees." Professor McKean makes pertinent observations on the growth of libraries (and the prestige of size), the proliferation of journals and the need for planned parenthood in this area, and the relation between the introduction of professional schools and library budgets. $\mathrm{He}$ is critical of the work of associations in urging the establishment of professional schools on a basis of pure rivalry. Regional cooperation in library purchasing and in establishing schools and departments is urged.

Dr. Robert B. Downs, director of the library and library school at the University of Illinois, provides an incisive review of "Library Cooperation and Specialization." Dr. Downs also refutes the statement that "librarians have been wasteful or inefficient in their expenditure of institutional funds." He traces the development of cooperative enterprises and efforts to specialize in collecting. He points out weaknesses in the undertakings, and makes the following pertinent observations: (1) cooperation has distinct limitations, (2) the best opportunities for cooperation are in specialized subjects and in little-used kinds of materials, (3) fewer obstacles to cooperation exist in locations where libraries are concentrated than in regions where distances are great and libraries are scattered, (4) possibilities for cooperation exist in areas with inadequate library resources, even though distances may be wide, (5) positive cooperation can be expanded in preservation of such materials as newspapers, local archives, and manuscripts, and coverage in foreign serial publications, maps, and research reports, and (6) no form of cooperation is a cure-all for all library problems.

Dr. Lewis C. Branscomb, director of libraries of Ohio State University, follows up some of the points made by Professor McKean and Dr. Downs in his discussion of "Library Specialization through Institutional Specialization." In addition to cooperative library projects, there is a need for universities getting together and cooperating on national and regional bases in regard to curricula. Activities in the South and West in this connection are cited. To this reviewer, such plans are likely to develop too slowly to aid libraries unless there is a national program supported by the AAU.

Discussion of these papers includes comments on the Midwest Inter-Library Center as an example of the way out for libraries, the proposed Northeastern Regional Library, developments in the Southeast, microphotographic reproduction and interlibrary loans, and how to get more out of cooperative cataloging. As Verner Clapp of the Library of Congress points out, much more can be done in the field of cataloging. If Professors Hamilton and Fruton are right about cataloging, perhaps Dr. Ralph E. Ellsworth's comments on full support for more effective centralized cataloging is more than a blind stab in the dark.

The fourth session was devoted to the "Financial Situation." This, of course, was the real reason for calling the conference, and will be the focus of attention of the proposed commission. Harvard's growth in its library budget from $\$ 600,000$ in 1937 to $\$ 2,340,000$ in 1954 is described by Dr. Keyes D. Metcalf in "Facing the Consequences of Growth." The problem of growth is not new, as Dr. Metcalf points out, but the profession will need to do something about it in the near future. $\mathrm{He}$ is convinced that presidents and professors will have to work closely with the librarians in the solution of the problem.

Mr. Donald Coney, writing of "A Librarian's View of Library Finance," opens his statement with the following comment: "I wish to state my position at the outset candidly: I believe that the universities of the United States, public and private, are collectively not spending enough money on books and on library services." Mr. Coney calls attention to savings which can be made in improvement of procedures. However, he concentrates his attention on wellplanned cooperative enterprises which will 
get libraries away from the "medieval state of individual acquisitiveness." Mr. Coney emphasizes also the need of work or performance budgets to show the relation of library services to appropriate university activities.

Discussion of this session was devoted to such matters as travel funds for scholars and for books (scholars going to where collections are, and possibly allowing collections to follow moving scholars), rivalry and specialization in collecting, the relation between financial problems and philosophical problems of education, and the pressure for expansion in terms of future needs. All of these are important problems for the consideration of the proposed commission.

The fifth and final session was devoted to "The Future." The statement of the AAU by its Special Committee on the Proposed Study describes the need for the study, its sponsorship, and scope. Dr. Paul Buck, newly appointed director of the Harvard University Library, provides the basic paper, "Looking Ahead." Dr. Buck takes a calm attitude toward the development of the university library. He is critical of librarians for having taken a negative approach to their problems. His credo in encouraging: (1) "the library is the heart of education," (2) "the library remains the great conservator of learning," (3) "quality education is impossible without a quality library," (4) "you cannot have a quality faculty without a quality library," (5) "a library is vital to proper exploitation of our intellectual resources," and (6) "the library is essential to maintenance of free access to ideas and to the functioning of the untrammeled mind." These, to Dr. Buck, are obvious truths, and librarians might well exploit them positively.

Mr. Williams has forestalled criticism of the discussions by indicating the exploratory nature of the conference. Most of the topics, if not all of them, have been on the agenda of the ARL and ACRL groups for many years. President Millett's original observations, whether or not they have been misinterpreted, have had some value in stirring thoughts anew. Dr. Buck's allaying comments should be taken in their proper perspective of the many problems facing research librarians. Speculation and guesswork need substantiation.-Maurice $F$. Tauber.

\section{Serial Publications}

Serial Publications; Their Place and Treatment in Libraries. By Andrew D. Osborn. Chicago: American Library Association, 1955. xiii, 309p. \$6.

Whatever else may be said of this book, it must be acclaimed as a landmark in the literature of professional librarianship. The mere fact of its having brought together the best thinking in the serials realm-heretofore scattered in innumerable small unmanageable parcels - would have been a sufficient gift for librarians young and old. But Dr. Osborn does not leave matters floating hither and yon as does altogether too much of our "impartial" professional writing. He sets up his problems, presents alternative points of view, and in all but a few cases (where, apparently, the weight of evidence is to him indecisive) he makes reasoned choices among available principles and practices.

A writer cannot be all things to all readers. Some of us will complain that the introductory pages on the history of serial publications are skimpy and unsatisfying. The author will reply with justification that these pages were designed only to set the stage with its magnitude, complexity and variety of problems. A few will say that the author's lengthy quotations from source materials are sometimes superfluous for readers with background and experience. Many will counter with the thought that such a combination of anthology and text is superb for the uninitiated librarians who make up a large population. Others will find fault with the overuse of large research libraries for example and authority. In mitigation of this genre of card-stacking, it may be said that only in these libraries can one find the full gamut of problems from the simplest to the most complex. Nevertheless, the emphasis on large library practice is unfortunate because, in matters relating to objectives, organization, division of labor, and personnel training, smaller institutions are radically different from their larger and richer relatives. Dr. Osborn was aware of this problem, but labored under the obvious difficulty of finding either a literature or a well-advertised sound experience upon which to draw toward a discussion of serial publications in 